This document is confidential and is proprietary to the American Chemical Society and its authors. Do not copy or disclose without written permission. If you have received this item in error, notify the sender and delete all copies.

\title{
Halogenated sodium-closo-dodecaboranes as solid-state ion conductors
}

\begin{tabular}{|r|l|}
\hline Journal: & Chemistry of Materials \\
\hline Manuscript ID & cm-2016-047977.R2 \\
\hline Manuscript Type: & Article \\
\hline Date Submitted by the Author: & n/a \\
\hline Complete List of Authors: & $\begin{array}{l}\text { Hansen, Bjarne; University of Aarhus, Interdisciplinary Nanoscience Center, } \\
\text { Department of Chemistry } \\
\text { Paskevicius, Mark; Aarhus Universitet, Chemistry } \\
\text { Jørgensen, Mathias; University of Aarhus, Interdisciplinary Nanoscience } \\
\text { Center, Department of Chemistry } \\
\text { Jensen, Torben; University of Aarhus, Interdisciplinary Nanoscience Center, } \\
\text { Department of Chemistry }\end{array}$ \\
\hline
\end{tabular}

\section{SCHOLARONE" Manuscripts}




\section{INTRODUCTION}

An array of renewable energy sources exist that offer both clean and sustainable energy. However, renewable energy sources are intermittent fluxes, whether energy is produced from wind, waves or the sun, thus require energy storage. Pumped hydroelectric or compressed air energy storage offer large energy capacities at relatively low cost, but rely on a geographically favourable location, which is not feasible in many parts of the world and may require power transmission over relatively long distances. One way to overcome these obstacles, and properly balance energy fluxes with energy demand is to implement energy storage units, which could include hydrogen storage, ammonia storage or batteries. ${ }^{1-6}$ Electrochemical storage devices, or batteries, already cover a wide range of applications including portable devices such as cell phones and laptops to medium scale devices, such as electric vehicles, up to large scale stationary and grid applications. ${ }^{7}$ Possibly, the most important factor in developing a large-scale energy storage solution is low cost, which has sparked the search for new materials that can provide next-generation energy storage devices.

Recently, complex hydrides and metal boranes have been investigated as solid state electrolytes. ${ }^{8-11} \mathrm{LiBH}_{4}$ shows fast Li-ion conductivity above a polymorphic phase transition, which can be stabilized to room temperature by anion substitution of $\mathrm{BH}_{4}^{-}$by $\mathrm{I}^{-12,13}$ or by nanoconfinement. ${ }^{14}$ Polyhedral anions such as the closo-boranes, $\left[\mathrm{B}_{10} \mathrm{H}_{10}\right]^{2-}$ and $\left[\mathrm{B}_{12} \mathrm{H}_{12}\right]^{2-}$, and monocarba-closo-boranes, $\left[\mathrm{CB}_{11} \mathrm{H}_{12}\right]^{-}$and $\left[\mathrm{CB}_{9} \mathrm{H}_{10}\right]^{-}$, have also been studied with re- markably high $\mathrm{Li}^{+}$or $\mathrm{Na}^{+}$conductivities. ${ }^{15-19}$ The high conductivity in these compounds is linked to the highly disordered high temperature polymorphs, where partially occupied cation sites and fast reorientational dynamics of the anion promote excellent cation mobility. Perchlorinated lithium-closo-boranes, $\mathrm{Li}_{2} \mathrm{~B}_{12} \mathrm{Cl}_{12}$ and $\mathrm{Li}_{2} \mathrm{~B}_{10} \mathrm{Cl}_{10}$, were proposed as liquid electrolytes in $\mathrm{Li} / \mathrm{SOCl}_{2}$ battery cells in the early 1980s, where the extraordinary stability of $\left[\mathrm{B}_{n} \mathrm{Cl}_{n}\right]^{2-}$-anions $(n=10,12)$ towards temperature and the $\mathrm{Li}$ anode were a significant advantage. ${ }^{20-22}$ The perchlorocloso-boranes would either be dissolved in $\mathrm{SOCl}_{2}{ }^{20}$ or in ethereal solvent mixtures of ether dimethoxyethane and cyclic ketal dioxolane. ${ }^{23} \mathrm{~A} \mathrm{Li}^{-\mathrm{TiS}_{2}}$ cell with a liquid $\mathrm{Li}_{2} \mathrm{~B}_{10} \mathrm{Cl}_{10}$ electrolyte showed excellent stability at $70{ }^{\circ} \mathrm{C}$ for 19 discharge-recharge cycles, however the capacity began to decrease when cycled at $110{ }^{\circ} \mathrm{C}^{22}$ Acids of perchlorocloso-boranes, $\mathrm{H}_{2} \mathrm{~B}_{10} \mathrm{Cl}_{10}$ and $\mathrm{H}_{2} \mathrm{~B}_{12} \mathrm{Cl}_{12}$, were also studied to potentially replace $\mathrm{H}_{3} \mathrm{PO}_{4}$ electrolytes in acidic fuel cells, but were found to have modest decomposition temperatures $\left(<200{ }^{\circ} \mathrm{C}\right) .^{24}$

While many electrochemical studies require electrolytes to be used at ambient temperature, some technologies require higher operating temperatures. The sodiumsulphur battery $(\mathrm{NaS})$ is comprised of a molten sodium anode and a molten sulphur cathode that are separated by a ceramic, Na-conducting $\beta-\mathrm{Al}_{2} \mathrm{O}_{3}$ electrolyte. $\mathrm{NaS}$ batteries operate at temperatures between $300-350{ }^{\circ} \mathrm{C}$ to keep the electrodes molten and provide sufficient $\mathrm{Na}$-ion flow through the $\beta$-alumina electrolyte. ${ }^{25} \mathrm{NaS}$ batteries offer high energy densities (theoretical specific energy 
$760 \mathrm{Wh} / \mathrm{kg}$ ), about three times greater than lead-acid batteries, and high stability. These properties make NaS batteries suited for large scale energy storage or load levelling of the electrical grid. ${ }^{26}$ Furthermore, the low-cost and high abundance of sodium, compared to lithium, makes sodium batteries a promising technology in the long term. It is essential to discover new solid state sodium electrolytes that may provide higher ion conductivity, mechanical strength, as well as chemical and thermal stability.

Here the structural, thermal and solid-state electrochemical properties of $\mathrm{Na}_{2} \mathrm{~B}_{12} X_{12}(X=\mathrm{H}, \mathrm{Cl}, \mathrm{Br}, \mathrm{I})$ are investigated. We solve the crystal structures of the low and high temperate polymorphs, denoted $\alpha-\mathrm{Na}_{2} \mathrm{~B}_{12} X_{12}$ and $\beta$ $\mathrm{Na}_{2} \mathrm{~B}_{12} X_{12}(X=\mathrm{Cl}, \mathrm{Br}, \mathrm{I})$. Structural trends are discussed and theoretical calculations are used to further understand the polymorphic transitions into fast ion conducting structures.

\section{EXPERIMENTAL SECTION}

Sample preparation. $\mathrm{Na}_{2} \mathrm{~B}_{12} X_{12}(X=\mathrm{H}, \mathrm{Cl}, \mathrm{Br}$, and I) were purchased from Katchem (Prague, Czech Republic) and in situ SR-PXD and TGA-DSC-MS was measured on the as received samples. Before impedance spectroscopy, the samples were heated to $200{ }^{\circ} \mathrm{C}$ under vacuum for two hours in order to remove coordinated water. Removal of the coordinated water is verified using TGA/DSC (Fig S9S11) and PXD (Fig $\mathrm{S}_{3}-\mathrm{S}_{5}$ ) as shown in supplementary information. The as received $\mathrm{Na}_{2} \mathrm{~B}_{12} \mathrm{Br}_{12}$ does not dissolve completely in $\mathrm{H}_{2} \mathrm{O}$, and a cloudy suspension is observed on top of the solution, which indicates the presence of an impurity. $\mathrm{Na}_{2} \mathrm{~B}_{12} \mathrm{Br}_{12}$ was further heated to $500{ }^{\circ} \mathrm{C}$ under vacuum for $30 \mathrm{~min}$ to remove impurities. As received $\mathrm{Na}_{2} \mathrm{~B}_{12} \mathrm{Cl}_{12}$ and $\mathrm{Na}_{2} \mathrm{~B}_{12} \mathrm{I}_{12}$ are both fully soluble in $\mathrm{H}_{2} \mathrm{O}$.

Thermal analysis. Thermogravimetric analysis and differential scanning calorimetry (TGA-DSC) was conducted on a PerkinElmer STA 6000 where samples $(\sim 20 \mathrm{mg})$ were placed in $\mathrm{Al}_{2} \mathrm{O}_{3}$ crucibles and heated $\left(\Delta T / \Delta t=5{ }^{\circ} \mathrm{C} / \mathrm{min}\right)$ under constant argon flow $(20 \mathrm{~mL} / \mathrm{min})$. The instrument was coupled to a Hiden Analytical HPR-2o quadrupole mass spectrometer for residual gas analysis.

Powder X-ray diffraction and structure solution. Insitu powder X-ray diffraction (PXD) data were collected at the I711 beamline at MAX II, Maxlab, Lund, Sweden with $\lambda$ $=0.9938 \AA$ on a Titan CCD 165 mm detector. The samples were placed in a sapphire capillary under argon using a custom made sample cell and heated with a hot air blower $\left(\Delta T / \Delta t=5{ }^{\circ} \mathrm{C} / \mathrm{min}\right) .{ }^{27} \mathrm{PXD}$ data for structure solution were obtained from the Poz.1 beamline at Petra III, DESY, Hamburg, Germany at $\lambda=0.20775 \AA$ on a PerkinElmer XRD1621CN3-EHS $410 \mathrm{~mm}$ detector or on a Rigaku Smart Lab diffractometer equipped with a $\mathrm{Cu}$ source $\left(\mathrm{K}_{\alpha_{1}}=\right.$ $1.540593 \AA$ A) from $0.5 \mathrm{~mm}$ glass capillaries sealed under argon. Structure solution was performed in FOX (Free objects for crystallography ${ }^{28}$ using rigid body $\mathrm{B}_{12} X_{12}$ anions $(X=\mathrm{Cl}, \mathrm{Br}, \mathrm{I})$ and the models were refined in FullProf. Further refinement of the $R T$-polymorphs was performed by keeping the boron cage rigid, while the halogens were
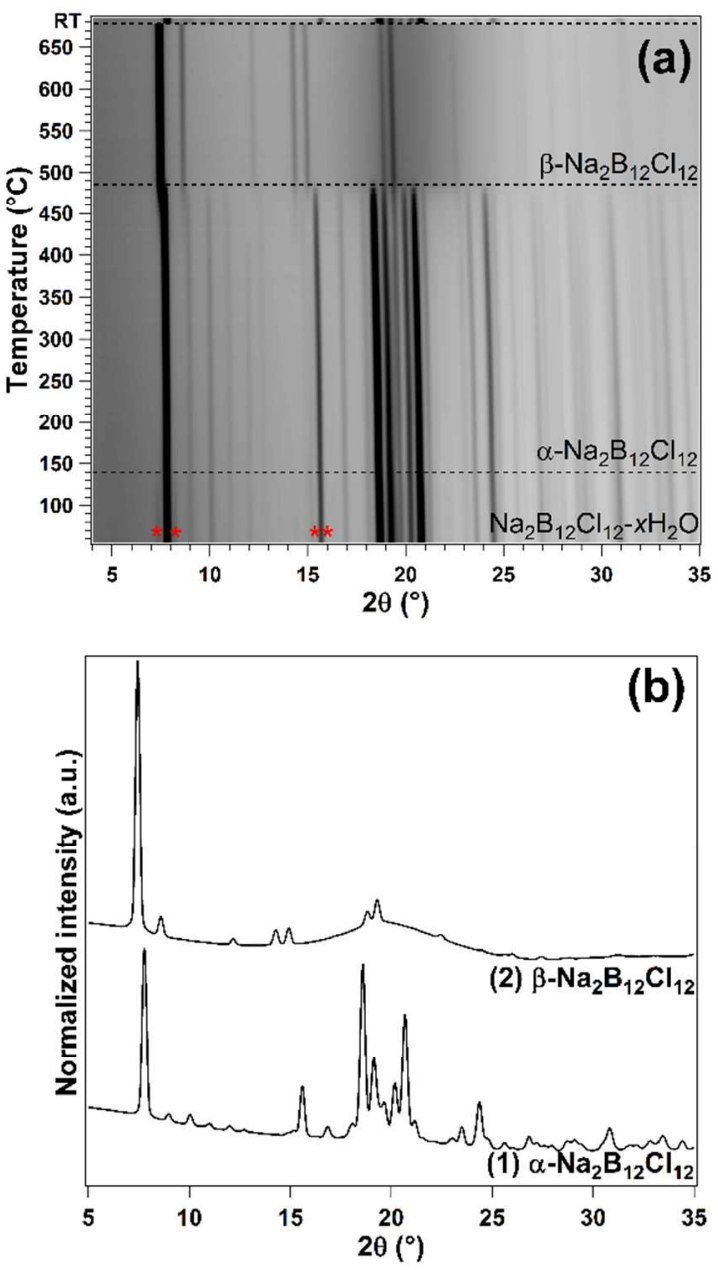

Figure 1. (a) in-situ SR-PXD measurement of $\mathrm{Na}_{2} \mathrm{~B}_{12} \mathrm{Cl}_{12}$ from $R T-670{ }^{\circ} \mathrm{C}\left(\Delta T / \Delta t=5{ }^{\circ} \mathrm{C} / \mathrm{min}\right), p(\mathrm{Ar})=1$ bar. The hydrated polymorph is marked with red asterisks. (b) Diffractograms of $\mathrm{Na}_{2} \mathrm{~B}_{12} \mathrm{Cl}_{12}$ obtained at (1) $T=150{ }^{\circ} \mathrm{C}$ showing diffracted intensity from $\alpha-\mathrm{Na}_{2} \mathrm{~B}_{12} \mathrm{Cl}_{12}$ and (2) $T=525{ }^{\circ} \mathrm{C}$ showing diffracted intensity from $\beta-\mathrm{Na}_{2} \mathrm{~B}_{12} \mathrm{Cl}_{12}(\lambda=0.9938 \AA)$.

refined independently. In the case of the $H T$-polymorphs the $\mathrm{Na}^{+}$ions were preliminarily omitted during structure solution in FOX and added to specific sites during refinement. Furthermore, the occupancy of $\mathrm{Na}$ was constrained to stoichiometric ratios. The broad humps were modelled as part of the background. However, they result from the average atomic distances in the structure arising from cation/anion dynamics.

Electrochemical impedance spectroscopy. EIS data were collected on a BioLogic MTZ-35 impedance analyser equipped with a high temperature sample holder (HTSH). Samples were pressed into $6 \mathrm{~mm}$ diameter pellets of ca. 1 $\mathrm{mm}$ thickness and $100 \mu \mathrm{m}$ gold foil was mechanically fixed to both sides before being placed between platinum electrodes. For comparison pellets were sputter coated with $150 \mathrm{~nm} \mathrm{Au}$ (see SI). Pellet densities after compression were between $82-97 \%$ of theoretical density for $\mathrm{Na}_{2} \mathrm{~B}_{12} X_{12}(X=\mathrm{Cl}, \mathrm{Br}, \mathrm{I})$. 
Table 1. Structural parameters of the $\alpha$ - and $\beta$-polymorphs of $\mathrm{Na}_{2} \mathrm{~B}_{12} X_{12}(X=\mathrm{Cl}, \mathrm{Br}, \mathrm{I})$ solved from this work together with other related compounds. See Tables S1-S6 and Figures S3-S8 for more information.

\begin{tabular}{|c|c|c|c|c|c|c|c|c|c|c|c|}
\hline Compound & $\begin{array}{l}\text { Crystal } \\
\text { system }\end{array}$ & $\begin{array}{l}\text { Space } \\
\text { group }\end{array}$ & $\begin{array}{l}\text { Anion } \\
\text { packing }\end{array}$ & $\begin{array}{l}a \\
{[\AA ̊]}\end{array}$ & $\begin{array}{l}b \\
[\AA]]\end{array}$ & $\begin{array}{l}c \\
{[\AA ̊]}\end{array}$ & $\begin{array}{l}\beta \\
{\left[{ }^{\circ}\right]}\end{array}$ & $Z$ & $\begin{array}{l}V \\
{\left[\AA^{3}\right]}\end{array}$ & $\begin{array}{l}V / Z \\
{\left[\AA^{3}\right]}\end{array}$ & Reference \\
\hline$\alpha-\mathrm{Na}_{2} \mathrm{~B}_{12} \mathrm{H}_{12}$ & monoclinic & $P_{21} / n$ & $* *$ & 7.0306 & 10.6540 & 7.0093 & 94.676 & 2 & 523.28 & 261.64 & 29 \\
\hline$\beta-\mathrm{Na}_{2} \mathrm{~B}_{12} \mathrm{H}_{12}$ & cubic & $I m-3 m$ & bcc & 8.098 & - & - & 90 & 2 & 531.0(1) & 265.50 & 30 \\
\hline$\alpha-\mathrm{Na}_{2} \mathrm{~B}_{12} \mathrm{Cl}_{12}$ & cubic & $\mathrm{Pa}-3$ & fcc & $12.6496(4)$ & - & - & 90 & 4 & 2024.09 & 506.02 & this work \\
\hline$\beta-\mathrm{Na}_{2} \mathrm{~B}_{12} \mathrm{Cl}_{12}$ & cubic & $\mathrm{Fm}-3 \mathrm{~m}$ & fcc & $13.2156(2)$ & - & - & 90 & 4 & 2308.15 & 577.04 & this work \\
\hline$\alpha-\mathrm{Na}_{2} \mathrm{~B}_{12} \mathrm{Br}_{12}$ & cubic & $P a-3$ & fcc & 13.1412(7) & - & - & 90 & 4 & 2269.42 & 567.36 & this work \\
\hline$\beta-\mathrm{Na}_{2} \mathrm{~B}_{12} \mathrm{Br}_{12}$ & cubic & $F m-3 m$ & fcc & $13.7700(7)$ & - & - & 90 & 4 & 2611.02 & 652.76 & this work \\
\hline$\alpha-\mathrm{Na}_{2} \mathrm{~B}_{12} \mathrm{I}_{12}$ & cubic & $\mathrm{Pa}-3$ & fcc & $14.0229(5)$ & - & - & 90 & 4 & 2757.49 & 689.37 & this work \\
\hline$\beta-\mathrm{Na}_{2} \mathrm{~B}_{12} \mathrm{I}_{12}$ & cubic & $F m-3 m$ & fcc & $14.6552(6)$ & - & - & 90 & 4 & 3147.62 & 786.91 & this work \\
\hline$\alpha-\mathrm{Cs}_{2} \mathrm{~B}_{12} \mathrm{Cl}_{12}$ & trigonal & $R-3$ & $\mathrm{fcc}^{*}$ & $9 \cdot 5967$ & - & 45.642 & 120 & 6 & 3640.3 & 606.72 & 31 \\
\hline$\alpha-\mathrm{Cs}_{2} \mathrm{~B}_{12} \mathrm{Br}_{12}$ & trigonal & $R-3$ & fcc* & $9 \cdot 9792$ & - & 47.664 & 120 & 6 & 4110.67 & 685.11 & 31 \\
\hline$\alpha-\mathrm{Cs}_{2} \mathrm{~B}_{12} \mathrm{I}_{12}$ & trigonal & $R-3$ & $\mathrm{fcc}^{*}$ & 10.4705 & - & 50.183 & 120 & 6 & 4764.55 & 794.09 & 31 \\
\hline$\alpha-\mathrm{Na}_{2} \mathrm{~B}_{10} \mathrm{H}_{10}$ & monoclinic & $P 2_{1} / c$ & $\mathrm{fcc}^{*}$ & 10.2828 & 13.0218 & 6.6734 & 93.754 & 4 & 891.65 & 222.91 & 32 \\
\hline$\beta-\mathrm{Na}_{2} \mathrm{~B}_{10} \mathrm{H}_{10}$ & cubic & $F m-3 m$ & fcc & 9.8426 & - & - & 90 & 4 & 953.52 & 238.38 & 16 \\
\hline$\alpha-\mathrm{NaCB}_{9} \mathrm{H}_{10}$ & orthorhombic & $\operatorname{Pnaz}_{1}$ & $* *$ & 9.9830 & 10.6367 & 7.8266 & 90 & 4 & 931.08 & 232.77 & 33 \\
\hline$\beta-\mathrm{NaCB}_{9} \mathrm{H}_{10}$ & trigonal & $P_{31 C}$ & - & 6.844 & - & 10.908 & 120 & 2 & 442.5 & 221.25 & 18 \\
\hline$\alpha-\mathrm{NaCB}_{11} \mathrm{H}_{12}$ & orthorhombic & $\mathrm{PCa}_{1}$ & $\mathrm{fcc}^{*}$ & 9.7821 & 9.6254 & 10.0928 & 90 & 4 & 950.30 & 237.57 & 17 \\
\hline$\beta-\mathrm{NaCB}_{11} \mathrm{H}_{12}$ & cubic & $F m-3 m$ & fcc & 10.066 & & - & 90 & 4 & 1019.93 & 254.98 & 17 \\
\hline
\end{tabular}

\section{* Slightly distorted cubic, ${ }^{* *}$ non-cubic.}

All measurements were conducted in an argon atmosphere $(1 \mathrm{bar})$ under variable temperature $\left(R T-670{ }^{\circ} \mathrm{C}\right)$ measured by a K-type thermocouple $\sim 5 \mathrm{~mm}$ from the sample. Impedance data were measured at $100 \mathrm{mV} \mathrm{AC}$ from 1 to $1 \times 10^{7} \mathrm{~Hz}$ after $1 \mathrm{~h}$ of thermal equilibrium in $25 / 50^{\circ} \mathrm{C}$ intervals from $100-600{ }^{\circ} \mathrm{C}$. Ion conductivity data $(\sigma)$ were derived from Nyquist impedance plots using the $\mathrm{R}_{1}+\left(\mathrm{Q}_{1} / \mathrm{R}_{2}\right)+$ Wo equivalent circuit to determine the $x$ intercept of the Nyquist semicircle and blocking tail $(I)$, the area of the pellet face $(A)$, and the pellet thickness $(t)$ according to: $\sigma=t /(I \cdot A)$. Q, R and Wo refer to constant phase elements, resistors and open circuit Warburg elements, respectively. $R_{1}$ is the internal resistance and $R_{2}$ is the charge transfer resistance. At temperatures below 150 ${ }^{\circ} \mathrm{C}$ the impedance spectroscopy data was difficult to interpret due to poor ion conductivity and data quality. Nyquist and bode plots are shown for selected temperatures in supporting information (Figure S12-S16).

Theoretical methods. All calculations were performed at the Hartree-Fock/3-21G level of theory using the software Gaussian ogW. ${ }^{34}$ Electrostatic potential surface maps were projected onto surfaces plotted at an isovalue of o.oo8 electrons/bohr ${ }^{3}$.

\section{RESULTS}

\section{Structural characterization}

The in situ SR-PXD data of as received $\mathrm{Na}_{2} \mathrm{~B}_{12} \mathrm{Cl}_{12}$, $\mathrm{Na}_{2} \mathrm{~B}_{12} \mathrm{Br}_{12}$, and $\mathrm{Na}_{2} \mathrm{~B}_{12} \mathrm{I}_{12}$ are presented in Figures $1, \mathrm{~S} 1$, and $\mathrm{S}_{2}$, respectively. All three compounds share structural similarities and behave comparably during thermal treatment. Briefly, $\mathrm{Na}_{2} \mathrm{~B}_{12} X_{12} \cdot x \mathrm{H}_{2} \mathrm{O}$ are dehydrated into $\alpha$ $\mathrm{Na}_{2} \mathrm{~B}_{12} X_{12}$ polymorphs before undergoing polymorphic transitions to $\beta-\mathrm{Na}_{2} \mathrm{~B}_{12} X_{12}$ at high temperature (Table 1 ). For the case of the perchlorinated compound, $\mathrm{Na}_{2} \mathrm{~B}_{12} \mathrm{Cl}_{12} \cdot x \mathrm{H}_{2} \mathrm{O}$ is present in the as received powder (red asterisks in Figure 1), but the compound is dehydrated above $150^{\circ} \mathrm{C}$ into the low temperature (LT) polymorph, $\alpha$ -
$\mathrm{Na}_{2} \mathrm{~B}_{12} \mathrm{Cl}_{12}$, which is observed until $480{ }^{\circ} \mathrm{C}$. At this temperature $\alpha-\mathrm{Na}_{2} \mathrm{~B}_{12} \mathrm{Cl}_{12}$ undergoes an order-disorder polymorphic transition to $\beta-\mathrm{Na}_{2} \mathrm{~B}_{12} \mathrm{Cl}_{12}$, in accordance with other alkali metal-closo-dodecaboranes. ${ }^{30,31,35,36}$ After heating to $670{ }^{\circ} \mathrm{C}$, a room temperature diffractogram shows the anhydrous LT $\alpha$-polymorph, demonstrating the remarkable thermal stability of $\mathrm{Na}_{2} \mathrm{~B}_{12} \mathrm{Cl}_{12}$, and showing that the $\alpha \leftrightarrow \beta$ polymorphic transition is reversible.

Figure $1 \mathrm{~b}$ shows diffractograms of $\mathrm{Na}_{2} \mathrm{~B}_{12} \mathrm{Cl}_{12}$ measured at 150 and $525^{\circ} \mathrm{C}$, i.e. $\alpha-\mathrm{Na}_{2} \mathrm{~B}_{12} \mathrm{Cl}_{12}$ and $\beta-\mathrm{Na}_{2} \mathrm{~B}_{12} \mathrm{Cl}_{12}$. The $\alpha-$ polymorph crystallizes in the cubic $\mathrm{Pa}-3$ space group (Table 1 ) and is isostructural to other metal-closododecaboranes including $\mathrm{Li}_{2} \mathrm{~B}_{12} \mathrm{H}_{12}$, $35,37 \mathrm{Ag}_{2} \mathrm{~B}_{12} \mathrm{H}_{12}{ }^{36}$ and $\mathrm{Ag}_{2} \mathrm{~B}_{12} \mathrm{Cl}_{12}{ }^{38}$ Here, the $\left[\mathrm{B}_{12} \mathrm{Cl}_{12}\right]^{2-}$ anions are arranged in cubic close packing with Na-atoms located in the $8 \mathrm{c}$ Wyckoff site, coordinating to three $\left[\mathrm{B}_{12} \mathrm{Cl}_{12}\right]^{2-}$ anions $\left(\mathrm{\eta}^{2}\right)$ thereby generating distorted $\left[\mathrm{NaCl}_{6}\right]$ octahedra (see Figure 2). The $\beta$-polymorphs show an increase in crystal symmetry and also exhibit a diffuse scattering background (broad humps at $2 \theta \approx 15-23^{\circ}$ in Figures 1 , S1, and S2) indicating dynamic motion of the polyhedral boron cages and metal cations. ${ }^{30,36,39}$ The dynamic motion of the anion is also apparent in the structure solution of $\beta$ $\mathrm{Na}_{2} \mathrm{~B}_{12} \mathrm{Cl}_{12}$ shown in Figure 3. The $\beta$-polymorph crystallizes in the cubic Fm-3m space group (Table 1). Just like the $\alpha$ polymorphs, the anions are arranged in cubic close packing, however rotational dynamics are clearly observed and modelled by partially occupied $\mathrm{B}_{12} X_{12}$ icosahedra, rotated about their origin. This behaviour is in line with several previously described high temperature metal-closoborane polymorphs, i.e. $\beta-M_{2} \mathrm{~B}_{12} \mathrm{H}_{12}(M=\mathrm{Li}, \mathrm{Na}, \mathrm{Ag})^{30,36}$ and $\beta-M_{2} \mathrm{~B}_{10} \mathrm{H}_{10}(M=\mathrm{Na}, \mathrm{Ag}){ }^{16,36}$ The Na-atoms in $\beta$ $\mathrm{Na}_{2} \mathrm{~B}_{12} \mathrm{Cl}_{12}$ are located in $4 b$ and $24 d$ Wyckoff sites with partial occupancies (0.53(6) and $0.24(1)$, respectively). The localization of the Na-atoms is challenging due to the high degree of disorder in the structure (partial occupancy and anion reorientation) and the high symmetry, 


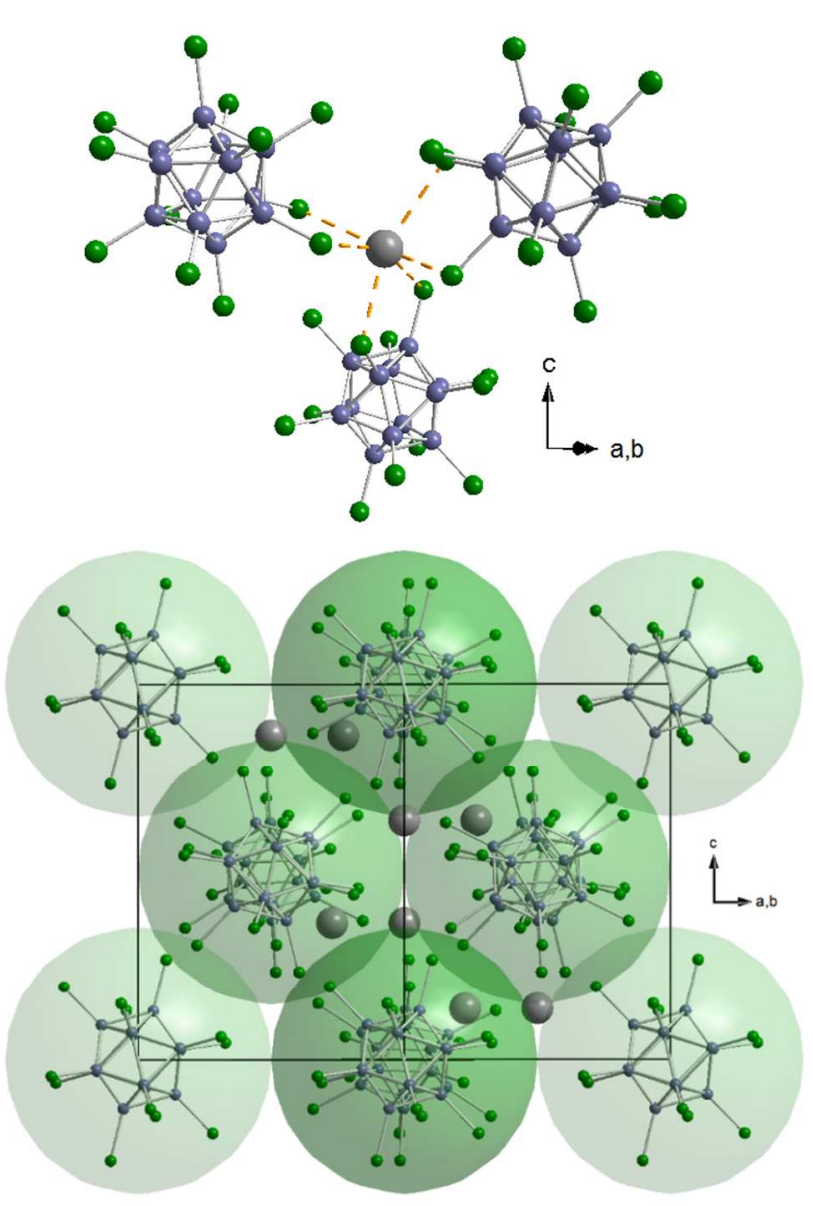

Figure 2. (top) Na-atoms octahedrally coordinated to 6 chlorine atoms and (bottom) the unit cell in $\alpha-\mathrm{Na}_{2} \mathrm{~B}_{12} \mathrm{Cl}_{12}(\mathrm{~Pa}-3)$. Small coloured spheres indicate $\mathrm{Na}$ (grey), $\mathrm{B}$ (blue grey), $\mathrm{Cl}$ (green) and the calculated radius of the $\left[\mathrm{B}_{12} \mathrm{Cl}_{12}\right]^{2-}$ anion is illustrated with large transparent, green spheres.

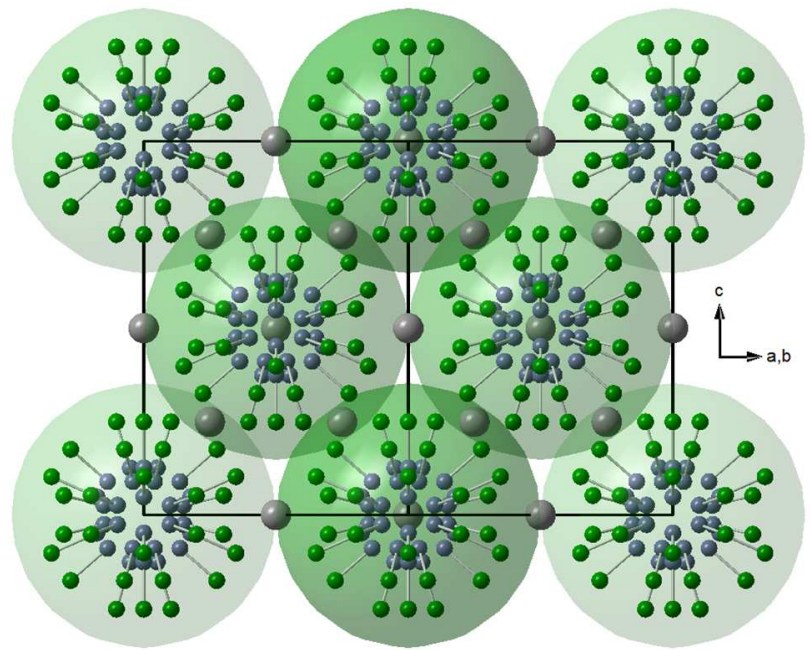

Figure 3. Unit cell in $\beta-\mathrm{Na}_{2} \mathrm{~B}_{12} \mathrm{Cl}_{12}(F m-3 m)$. Small coloured spheres indicate partially occupied $\mathrm{Na}$ (grey), B (blue grey), $\mathrm{Cl}$ (green) and the calculated radius of the disordered $\left[\mathrm{B}_{12} \mathrm{Cl}_{12}\right]^{2-}$ anion is illustrated with large transparent, green spheres. Dynamic disorder is modelled by partially occupied icosahedra, rotated about their origin.

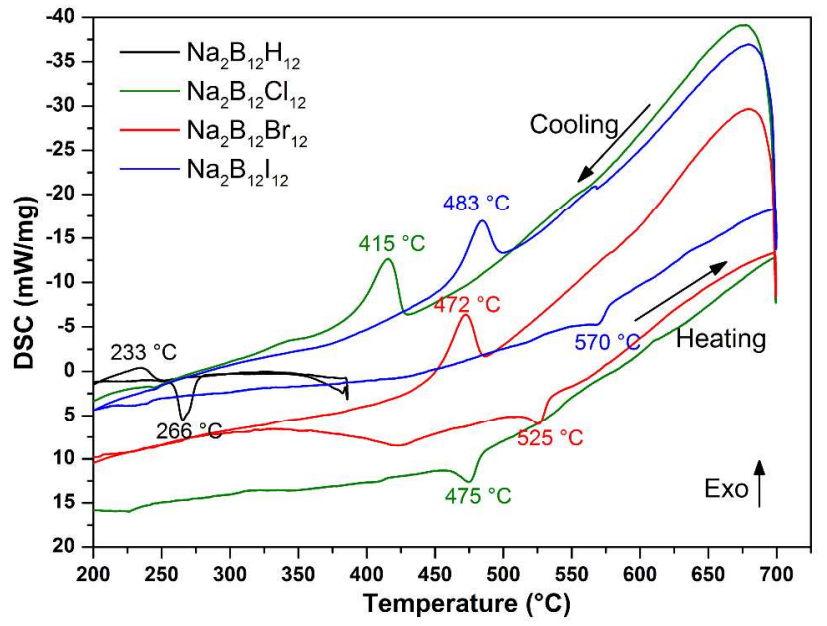

Figure 4. DSC data of $\mathrm{Na}_{2} \mathrm{~B}_{12} X_{12}(X=\mathrm{H}, \mathrm{Cl}, \mathrm{Br}, \mathrm{I})$ in the temperature range $R T-380{ }^{\circ} \mathrm{C}$ or $R T-700{ }^{\circ} \mathrm{C}(\Delta T / \Delta t= \pm 5$ ${ }^{\circ} \mathrm{C} / \mathrm{min}, \mathrm{Ar}$ flow $=20 \mathrm{~mL} / \mathrm{min}$ ).

which provide a relatively low number of diffraction peaks.

In situ SR-PXD experiments of $\mathrm{Na}_{2} \mathrm{~B}_{12} \mathrm{Br}_{12}$ and $\mathrm{Na}_{2} \mathrm{~B}_{12} \mathrm{I}_{12}$ are shown in Figure $S_{1}$ and $S_{2}$. The $\alpha$ - and $\beta$-polymorphs of $\mathrm{Na}_{2} \mathrm{~B}_{12} \mathrm{Br}_{12}$ and $\mathrm{Na}_{2} \mathrm{~B}_{12} \mathrm{I}_{12}$ are isostructural to those observed for $\mathrm{Na}_{2} \mathrm{~B}_{12} \mathrm{Cl}_{12}$, but shifted slightly towards lower $2 \theta$ in the diffractograms in agreement with the bigger anions and thus larger unit cell volumes. The crystallographic data is summarized in Table 1.

\section{Trends in thermal behaviour}

Reversible polymorphic transitions can be observed during thermal treatment as endothermic or exothermic events during heating and cooling, respectively. Differential scanning calorimetry (DSC) data of the as received $\mathrm{Na}_{2} \mathrm{~B}_{12} X_{12}(X=\mathrm{H}, \mathrm{Cl}, \mathrm{Br}, \mathrm{I})$ are presented in Figure 4 where an endothermic event from the polymorphic transition $(\alpha \rightarrow \beta)$ can be seen during heating. Exothermic events are also observed upon cooling $(\beta \rightarrow \alpha)$ with peak temperatures listed in Table 2. A hysteresis effect of $33-83{ }^{\circ} \mathrm{C}$ is exhibited in all samples. The transition temperatures observed upon heating correlate well with those observed in the in situ SR-PXD measurements, however, the obtained values for $\mathrm{Na}_{2} \mathrm{~B}_{12} \mathrm{H}_{12}, \mathrm{Na}_{2} \mathrm{~B}_{12} \mathrm{Cl}_{12}$ and $\mathrm{Na}_{2} \mathrm{~B}_{12} \mathrm{I}_{12}$ deviate by $10-30{ }^{\circ} \mathrm{C}$ compared to an earlier report with a higher heating rate of $20{ }^{\circ} \mathrm{C} / \mathrm{min}$, as expected.$^{40} \mathrm{Na}_{2} \mathrm{~B}_{12} \mathrm{Br}_{12}$ shows two endothermic events upon heating. The event at $T=$ $425^{\circ} \mathrm{C}$ is not observed by in situ SR-PXD, but is expected to be an amorphous impurity, which is observed by a 2.0 wt $\%$ mass loss in TGA measurements (Figure S1o). Minor mass loss $(<0.5 \mathrm{wt} \%)$ is observed in all samples, typically above $500{ }^{\circ} \mathrm{C}$, which indicates partial decomposition.

The order-disorder phase transition temperatures, $T_{\text {Trans }}$, observed during heating in the DSC are plotted vs. the volume per formula unit $(V / Z)$ in Figure 5, and follow a trend with $T_{\text {Trans }}$ as a function of anion volume. This indicates the polymorphic transition temperature can be tuned by the cation/anion size ratio. A similar trend was 


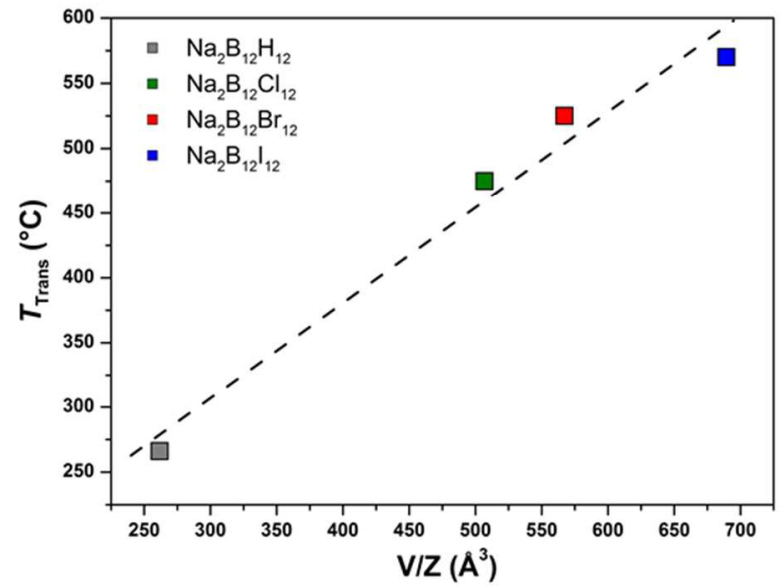

Figure 5. Temperature for polymorphic transition, $T_{\text {Trans }}$, of $\mathrm{Na}_{2} \mathrm{~B}_{12} X_{12}(X=\mathrm{H}, \mathrm{Cl}, \mathrm{Br}, \mathrm{I})$ versus the volume of one formula unit.

Table 2. Transition temperatures, $T_{\text {Trans }}$, observed in DSC data of $\mathrm{Na}_{2} \mathrm{~B}_{12} X_{12}(X=\mathrm{H}, \mathrm{Cl}, \mathrm{Br}, \mathrm{I})$ during heating and cooling $\left(\Delta T / \Delta t=5{ }^{\circ} \mathrm{C} / \mathrm{min}\right)$. The hysteresis is listed as the difference between $T_{\text {Trans }}$ observed during heating and cooling. Previously reported values obtained using a heating rate of 20 ${ }^{\circ} \mathrm{C} / \mathrm{min}$ in $\mathrm{He}$ atmosphere are listed in parenthesis. ${ }^{40}$

\begin{tabular}{llll}
\hline Sample & $\begin{array}{l}T_{\text {Trans }} \text { heating } \\
{\left[{ }^{\circ} \mathrm{C}\right]}\end{array}$ & $\begin{array}{l}T_{\text {Trans }} \text { cooling } \\
{\left[{ }^{\circ} \mathrm{C}\right]}\end{array}$ & $\begin{array}{l}\text { Hysteresis } \\
{\left[{ }^{\circ} \mathrm{C}\right]}\end{array}$ \\
\hline $\mathrm{Na}_{2} \mathrm{~B}_{12} \mathrm{H}_{12}$ & $266(256)$ & $233(203)$ & $33(53)$ \\
$\mathrm{Na}_{2} \mathrm{~B}_{12} \mathrm{Cl}_{12}$ & $475(457)$ & $415(423)$ & $60(34)$ \\
$\mathrm{Na}_{2} \mathrm{~B}_{12} \mathrm{Br}_{12}$ & 525 & 472 & 53 \\
$\mathrm{Na}_{2} \mathrm{~B}_{12} \mathrm{I}_{12}$ & $570(543)$ & $483(499)$ & $87(44)$ \\
\hline
\end{tabular}

observed for the alkali metal borohydrides, $\mathrm{MBH}_{4}(M=\mathrm{Li}$, $\mathrm{Na}, \mathrm{K}, \mathrm{Rb}, \mathrm{Cs})^{41}$ and for $M_{2} \mathrm{~B}_{12} \mathrm{H}_{12}(M=\mathrm{K}, \mathrm{Rb}, \mathrm{Cs}),{ }^{42}$ however for $\mathrm{Cs}_{2} \mathrm{~B}_{12} X_{12}(X=\mathrm{Cl}, \mathrm{Br}, \mathrm{I})$ the transition temperatures are erratically scattered between $180-312{ }^{\circ} \mathrm{C}$ despite being isostructural in space group $R-3 \cdot{ }^{31}$ The increasing mass of the anions in the series $\mathrm{B}_{12} X_{12}{ }^{2-}(X=\mathrm{H}, \mathrm{Cl}, \mathrm{Br}, \mathrm{I})$ of $141.83,555.16,1088.58$ and $1652.58 \mathrm{~g} / \mathrm{mol}$ may also contribute to the increasing polymorphic transition temperatures.

\section{Ion conductivity}

The ion conductivity of $\mathrm{Na}_{2} \mathrm{~B}_{12} X_{12}(X=\mathrm{Cl}, \mathrm{Br}, \mathrm{I})$ is shown in Figure 6 together with the reported conductivity of related sodium-closo-boranes, sodium-monocarba-closoboranes and solid state sodium-electrolytes. The ion conductivity for all three halogenated boranes is much lower than for their hydrogen-analogues near ambient temperatures. However, the conductivity increases steadily with temperature and near the polymorphic transition temperatures the ion conductivity exponentially increases, akin to $\mathrm{Na}_{2} \mathrm{~B}_{12} \mathrm{H}_{12}{ }^{15}$ The ion conductivities of the halogenated sodium-closo-boranes are similar to one another and all show excellent $\mathrm{Na}^{+}$conductivity above their polymorphic phase transition ( $0.014-0.162 \mathrm{~S} / \mathrm{cm}$ ). The ion conductivity appears to follow a trend at high temperature where $\mathrm{Na}_{2} \mathrm{~B}_{12} \mathrm{Cl}_{12}>\mathrm{Na}_{2} \mathrm{~B}_{12} \mathrm{Br}_{12}>\mathrm{Na}_{2} \mathrm{~B}_{12} \mathrm{I}_{12}$. This mirrors the unit cell volumes of the compounds, perhaps because

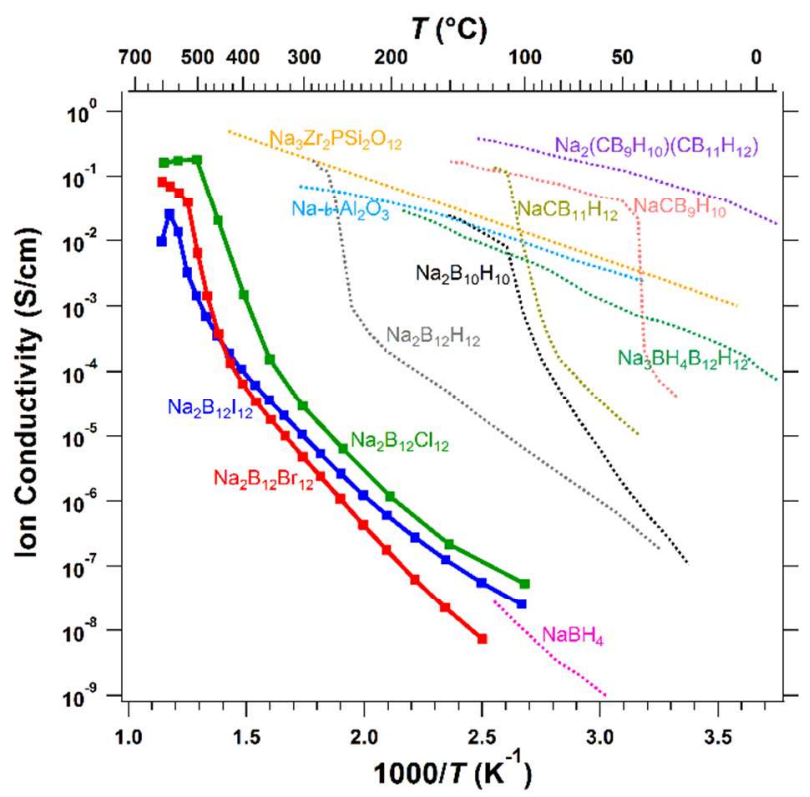

Figure 6. Ion conductivity of $\mathrm{Na}_{2} \mathrm{~B}_{12} X_{12}(X=\mathrm{Cl}, \mathrm{Br}$, I) and related Na-borane compounds and $\mathrm{Na}$-electrolytes as a function of inverse temperature. ${ }^{15,19,43-46}$

$\mathrm{Na}-\mathrm{Na}$ jump distances are shortest in $\mathrm{Na}_{2} \mathrm{~B}_{12} \mathrm{Cl}_{12}$, which shows the highest ion conductivity. The ion conductivity decreases above the transition temperature, which is due to slow decomposition. A gradual mass loss at high temperatures was observed by TGA in all halogenated sodium-closo-dodecaborane samples (Figures S9 - S11) indicating the samples partially decompose above their polymorphic transition, which in turn reduces ion conductivity. This is further underlined by the presence of a coloured film deposited on the interior glass walls of the EIS sample holder observed after cooling. For $\mathrm{Na}_{2} \mathrm{~B}_{12} \mathrm{Cl}_{12}$ the deposition had a white hue, a red hue for $\mathrm{Na}_{2} \mathrm{~B}_{12} \mathrm{Br}_{12}$ and a yellow hue for $\mathrm{Na}_{2} \mathrm{~B}_{12} \mathrm{I}_{12}$. This is in contrast to the in situ SR-PXD measurements where all samples appear stable at high temperatures.

\section{DISCUSSION}

The ion conductivity of the halogenated sodium-closoboranes (up to $0.162 \mathrm{~S} / \mathrm{cm}$ ) reaches that of the most promising $\mathrm{Na}^{+}$ion conductors, albeit at much higher temperatures $\left(>400{ }^{\circ} \mathrm{C}\right)$. In fact, all sodium closo-boranes and -carboranes have similar ion conductivities (typically $0.01-0.1 \mathrm{~S} / \mathrm{cm}$ ) above their polymorphic phase transformation temperature. This is a good indication that all of these boranes share a property that enables 'liquid-like' conduction. The similarity is of course structural, where all compounds display partial cation occupancy of the available crystallographic sites and reorientational anion dynamics. From geometric arguments the bcc lattice is preferred for cation diffusion in solid state electrolytes, at least for more covalent oxide- or sulphide-rich frameworks. ${ }^{47}$ However, most of the metal-closo-boranes studied to date have $f c c$ arrangements in their high temperature polymorph, as seen in Table 1. One of the highest conductivities is observed in $\mathrm{NaCB}_{9} \mathrm{H}_{10}$ with hexagonally arranged anions. 
$\mathrm{BH}_{4}^{-}$

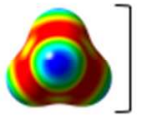

$3.14 \AA$

$-0.265=-0.230$

$\mathrm{B}_{12} \mathrm{~F}_{12}{ }^{2-}$

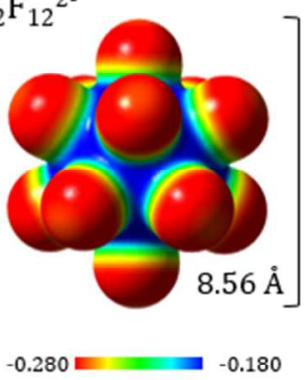

$\mathrm{B}_{10} \mathrm{H}_{10}{ }^{2-}$

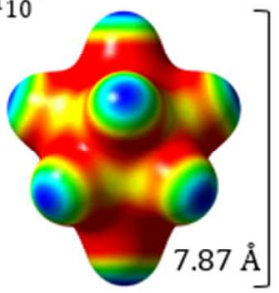

$-0.315=0.270$

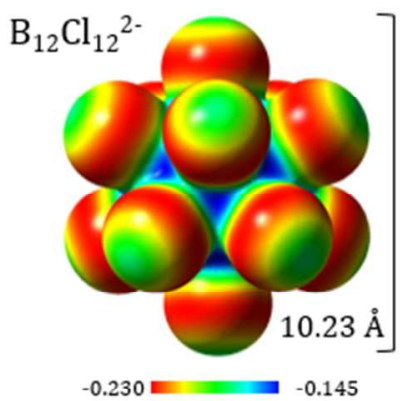

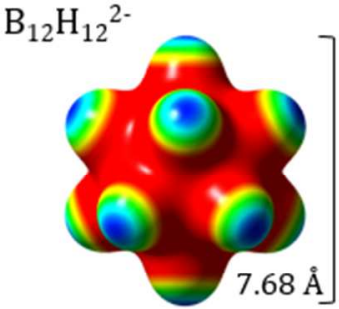
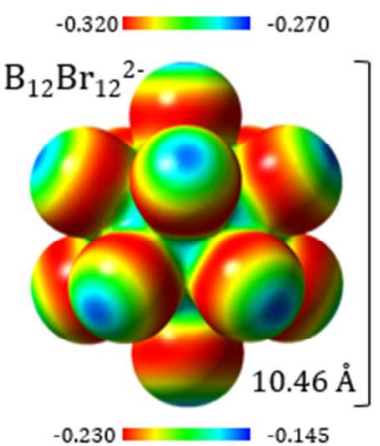

$\mathrm{CB}_{11} \mathrm{H}_{12}$

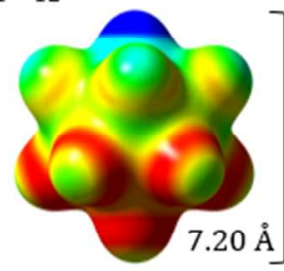

$7.20 \AA$

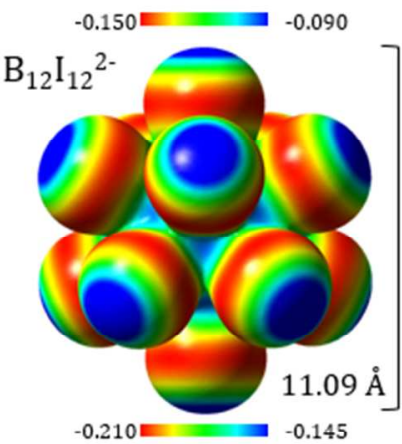

more negative less negative

Figure 7. Electrostatic potential surface maps for isolated borane anions calculated using the HF/3-21G level of theory. Anions are displayed at relative sizes with surfaces plotted at an isovalue of 0.008 electrons/bohr ${ }^{3}$. The electrostatic potential is displayed in atomic units $(1 \mathrm{a} . \mathrm{u} .=2.625 \mathrm{MJ} / \mathrm{mol})$ and the length of the anion isosurface, defined by the bracket, is also displayed. These values are larger than anion sizes extracted from solid state crystal structures.

Thus several other factors influence the ion conductivity, and their relationship is not yet fully understood. The question remains as to why the ion conductivity of the halogenated closo-boranes is poor at room temperature. $\alpha-\mathrm{Na}_{2} \mathrm{~B}_{12} X_{12}(X=\mathrm{Cl}, \mathrm{Br}, \mathrm{I})$ all share the same structure as $\alpha$ $\mathrm{Li}_{2} \mathrm{~B}_{12} \mathrm{H}_{12}$ and $\alpha-\mathrm{Ag}_{2} \mathrm{~B}_{12} \mathrm{H}_{12}$, which are orders of magnitude better ion conductors near room temperature. There does not appear to be a trend between the ion conductivity and the volume per formula unit in the unit cell or the anion packing (Table 1). However, one clear difference between the halogenated closo-boranes and other metal closoboranes is the halogen atoms in the anion. The overall anion charge remains constant in $\left[\mathrm{B}_{12} X_{12}\right]^{2-}$ for $X=\mathrm{H}, \mathrm{F}, \mathrm{Cl}$, $\mathrm{Br}$, I, but there are clear differences in the distribution of charge density around the anion. The electron density in covalently bound halogen atoms $(\mathrm{B}-X)$ is anisotropically distributed around the halogen in a belt (red bands around $\mathrm{Cl}, \mathrm{Br}$, and $\mathrm{I}$ in Figure 7 ), leading to a more positively charged tip of the isolated anion. ${ }^{48}$ The charge anisotropy of the halogens follows the trend $\mathrm{F}<\mathrm{Cl}<\mathrm{Br}<\mathrm{I}$, where iodine can undergo the strongest directional halogen bonding. A study into the charge distribution in haloboranes $\left(\mathrm{BH}_{2} X, X=\mathrm{F}, \mathrm{Cl}, \mathrm{Br}, \mathrm{I}\right)$ has revealed different types of $\sigma$-hole and $\pi$-hole non-covalent interactions in the solid-state that exhibit different bonding strengths and geometries. ${ }^{49}$ The directional charge distribution on the halogen atoms in $\left[\mathrm{B}_{12} X_{12}\right]^{2-}$ anions may lead to strong directional bonds to $\mathrm{Na}^{+}$and increase the resistance to reorientational anion disorder in the structure, forcing the polymorphic phase transition to high temperature. In fact, sodium is bound in a deep electrostatic potential well, in-between two halide atoms on the $\left[\mathrm{B}_{12} X_{12}\right]^{2-}$ anion $\left(\eta^{2}\right)$, also observed for silver in $\mathrm{Ag}_{2} \mathrm{~B}_{12} \mathrm{Cl}_{12} .{ }^{38}$ This coordination could lock the anion and cation together more strongly for small to moderately sized cations such as sodium. Accordingly, the larger, low charge density caesium atom in $\mathrm{Cs}_{2} \mathrm{~B}_{12} X_{12}$ undergoes tridentate $\left(\eta^{3}\right)$ bonding to the $\left[\mathrm{B}_{12} X_{12}\right]^{2-}$ anion. ${ }^{31}$ As such, it is interesting to note that $\mathrm{Cs}_{2} \mathrm{~B}_{12} \mathrm{I}_{12}$ has a lower polymorphic transition temperature than $\mathrm{Na}_{2} \mathrm{~B}_{12} \mathrm{I}_{12}\left(301{ }^{\circ} \mathrm{C}\right.$ compared to $\left.570{ }^{\circ} \mathrm{C}\right),{ }^{31}$ possibly due to the differences in bonding and charge density $\left(\mathrm{Cs}^{+}=\right.$ $\left.40.3 \mathrm{e} / \mathrm{nm}^{3}, \mathrm{Na}^{+}=152.9 \mathrm{e} / \mathrm{nm}^{3}\right)$. The low charge density could lead to a weaker electrostatic interaction between the cation and the anisotropically charged halogen atoms, allowing a reorientationally disordered polymorph to be favourable at lower temperatures. Heavier halogenated closo-boranes may also have a greater energy barrier to dynamic motion due to their increased anion mass. Indepth, combined theoretical and experimental dynamic studies into an array of closo-boranes may provide new knowledge about the anion reorientational mechanism and its dependence on anion-type. For instance, a onedimensional conduction pathway was found for $\mathrm{Cs}^{+}$in tetragonal $\mathrm{Cs}\left[\mathrm{B}_{9} \mathrm{C}_{2} \mathrm{H}_{12}\right]$ due to the short $\mathrm{Cs}-\mathrm{Cs}$ site distance down the $c$-axis. ${ }^{50}$ Despite this, three-dimensional conduction is expected for the cubic closo-boranes because the cation distances are uniform down all axes. Single crystal growth is required to fully elucidate the directionality of the ion conduction. However, a solvated crystal of $\mathrm{Na}_{2} \mathrm{~B}_{12} X_{12}(X=\mathrm{Cl}, \mathrm{Br}, \mathrm{I})$ would form and decrepitate upon solvent removal.

\section{CONCLUSIONS}

The perhalogenated closo-boranes, $\mathrm{Na}_{2} \mathrm{~B}_{12} X_{12}$, exhibit polymorphic transitions at high temperature $(475-570$ 
$\left.{ }^{\circ} \mathrm{C}\right)$ to structures with cation and anion dynamics. There is a clear trend in increasing transition temperature with increasing anion size and mass $(\mathrm{H}<\mathrm{Cl}<\mathrm{Br}<\mathrm{I})$. The halogenated closo-boranes show high thermal stability up to ca. $500{ }^{\circ} \mathrm{C}$, but slowly decompose above their polymorphic transition. The decomposition products remain unidentified but may involve the polymerisation of $\mathrm{B}_{12} X_{12}{ }^{2-}$ anions into other stable moieties, such as $\mathrm{B}_{24} X_{18}{ }^{2-5^{11}}$ The ambient temperature structures for $\alpha-\mathrm{Na}_{2} \mathrm{~B}_{12} X_{12}$ are all isostructural in cubic $\mathrm{Pa}-3$ and transition into $\mathrm{Fm}-3 \mathrm{~m}$ at high temperature $\left(\beta-\mathrm{Na}_{2} \mathrm{~B}_{12} X_{12}\right)$ where $\mathrm{Na}^{+}$positions are partially occupied and $\left[\mathrm{B}_{12} X_{12}\right]^{2-}$ anions are reorientationally disordered. The ion conductivity of the halogenated sodium-closo-boranes is similar to that of $\mathrm{Na}_{2} \mathrm{~B}_{12} \mathrm{H}_{12}$, but shifted $\sim 200{ }^{\circ} \mathrm{C}$ towards higher temperatures. Thus, ion conductivity remains relatively low at temperatures $<400$ ${ }^{\circ} \mathrm{C}$, which makes the potential use of halogenated sodiumcloso-boranes as electrolytes in technical applications questionable in their pure form. Although, modifications to the pure compounds may reduce polymorphic transition temperatures, which could yield stable materials with high ion conductivity at moderate temperatures. For instance, $\mathrm{Na}_{3} \mathrm{BH}_{4} \mathrm{~B}_{12} \mathrm{H}_{12}$ and $\mathrm{Na}_{2}\left(\mathrm{CB}_{9} \mathrm{H}_{10}\right)\left(\mathrm{CB}_{11} \mathrm{H}_{12}\right)$ show significantly improved $R T$ ion conductivities compared to their constituents. ${ }^{19,46}$ The cause of the high transition temperature for $\mathrm{Na}_{2} \mathrm{~B}_{12} X_{12}$, in contrast to $\mathrm{Na}_{2} \mathrm{~B}_{12} \mathrm{H}_{12}$, could be related to directional and more covalent cation-anion bonding, and the large anion size and anion mass, which restrict anion dynamics at low temperatures. Improving knowledge of these aspects may form the basis for a new tool to design fast ion conducting solids for novel types of batteries. Even though solid-state ion conductivities are limited to high temperatures for pure compounds, the halogenated closo-boranes may also play a role in aqueous and non-aqueous liquid electrolytes in the near future due to their extreme stabilities.

\section{ASSOCIATED CONTENT}

Supporting Information. In situ SR-PXD, Rietveld refinements, atomic coordinates, TGA-DSC, Bode and Nyquist plots. This material is available free of charge via the Internet at http://pubs.acs.org.

\section{AUTHOR INFORMATION}

\section{Corresponding Author}

* Torben R. Jensen: tri@chem.au.dk and Mark Paskevicius: m.paskevicius@curtin.edu.au

\section{Author Contributions}

The manuscript was written through contributions of all authors. All authors have given approval to the final version of the manuscript.

\section{ACKNOWLEDGMENT}

MP acknowledges financial support from The Danish Council for Independent Research for DFF Mobility 1325-00072. We are grateful to the Carlsberg Foundation and Danish Council for Independent Research, DFF 4181-00462 (HyNanoBorN), The Innovation Fund Denmark (HyFill-Fast) and the Danish National Research Foundation, Center for Materials Crystal- lography (DNRF93). Parts of this research were carried out at the light source Petra III at DESY, a member of the Helmholtz Association (HGF), and at beamline I711, in the research laboratory MAXIV, MAX II synchrotron, Lund, Sweden.

\section{REFERENCES}

(1) Chen, H.; Cong, T. N.; Yang, W.; Tan, C.; Li, Y.; Ding, Y. Progress in Electrical Energy Storage System: A Critical Review. Prog. Nat. Sci. 2009, 19 (3), 291-312.

(2) Liu, C.; Li, F.; Ma, L.-P.; Cheng, H.-M. Advanced Materials for Energy Storage. Adv. Mater. 2010, 22 (8), E28-E62.

(3) Dunn, B.; Kamath, H.; Tarascon, J.-M. Electrical Energy Storage for the Grid: A Battery of Choices. Science 2011, 334 (6058), 928-935.

(4) Lovegrove, K.; Luzzi, A.; Soldiani, I.; Kreetz, H. Developing Ammonia Based Thermochemical Energy Storage for Dish Power Plants. Sol. Energy 2004, $76(1-3)$, 331-337.

(5) Ley, M. B.; Jepsen, L. H.; Lee, Y.-S.; Cho, Y. W.; Bellosta von Colbe, J. M.; Dornheim, M.; Rokni, M.; Jensen, J. O.; Sloth, M.; Filinchuk, Y.; Jørgensen, J. E.; Besenbacher, F.; Jensen, T. R. Complex Hydrides for Hydrogen Storage - New Perspectives. Mater. Today 2014, 17 (3), 122-128.

(6) Jepsen, L. H.; Ley, M. B.; Černý, R.; Lee, Y.-S.; Cho, Y. W.; Ravnsbæk, D.; Besenbacher, F.; Skibsted, J.; Jensen, T. R. Trends in Syntheses, Structures, and Properties for Three Series of Ammine Rare-Earth Metal Borohydrides, $\mathrm{M}\left(\mathrm{BH}_{4}\right)_{3} \cdot \mathrm{nNH}_{3}(\mathrm{M}=\mathrm{Y}, \mathrm{Gd}$, and Dy). Inorg. Chem. 2015, 54 (15), 7402-7414.

(7) Reddy, T. Linden's Handbook of Batteries, 4th Edition; McGraw Hill Professional, 2010.

(8) Hansen, B. R. S.; Paskevicius, M.; Li, H.-W.; Akiba, E.; Jensen, T. R. Metal Boranes: Progress and Applications. Coord. Chem. Rev. 2016, 323, 6o-70.

(9) Paskevicius, M.; Jepsen, L. H.; Schouwink, P.; Černý, R.; Ravnsbæk, D. B.; Filinchuk, Y.; Dornheim, M.; Besenbacher, F.; Jensen, T. R. Metal Borohydrides and Derivatives - Synthesis, Structure and Properties. Chem. Soc. Rev. 2017, 46 (5), 15651634.

(10) Jongh, P. E. de; Blanchard, D.; Matsuo, M.; Udovic, T. J.; Orimo, S. Complex Hydrides as Room-Temperature Solid Electrolytes for Rechargeable Batteries. Appl. Phys. A 2016, 122 (3), 251.

(11) Mohtadi, R.; Orimo, S. The Renaissance of Hydrides as Energy Materials. Nat. Rev. Mater. 2016, 2, 16091 .

(12) Matsuo, M.; Nakamori, Y.; Orimo, S.; Maekawa, H.; Takamura, H. Lithium Superionic Conduction in Lithium Borohydride Accompanied by Structural Transition. Appl. Phys. Lett. 2007, 91 (22), 224103.

(13) Maekawa, H.; Matsuo, M.; Takamura, H.; Ando, M.; Noda, Y.; Karahashi, T.; Orimo, S. HalideStabilized $\mathrm{LiBH}_{4}$, a Room-Temperature Lithium 
Fast-Ion Conductor. J. Am. Chem. Soc. 2009, 131 (3), 894-895.

(14) Blanchard, D.; Nale, A.; Sveinbjörnsson, D.; Eggenhuisen, T. M.; Verkuijlen, M. H. W.; Suwarno; Vegge, T.; Kentgens, A. P. M.; de Jongh, P. E. Nanoconfined $\mathrm{LiBH}_{4}$ as a Fast Lithium Ion Conductor. Adv. Funct. Mater. 2015, 25 (2), 184-192.

(15) Udovic, T. J.; Matsuo, M.; Unemoto, A.; Verdal, N.; Stavila, V.; Skripov, A. V.; Rush, J. J.; Takamura, $\mathrm{H}$; O Orimo, S. Sodium Superionic Conduction in $\mathrm{Na}_{2} \mathrm{~B}_{12} \mathrm{H}_{12}$. Chem. Commun. 2014, 50 (28), 37503752.

(16) Udovic, T. J.; Matsuo, M.; Tang, W. S.; Wu, H.; Stavila, V.; Soloninin, A. V.; Skoryunov, R. V.; Babanova, O. A.; Skripov, A. V.; Rush, J. J.; Unemoto, A.; Takamura, H.; Orimo, S. Exceptional Superionic Conductivity in Disordered Sodium DecahydroCloso-Decaborate. Adv. Mater. 2014, 26 (45), 76227626.

(17) Tang, W. S.; Unemoto, A.; Zhou, W.; Stavila, V.; Matsuo, M.; Wu, H.; Orimo, S.; Udovic, T. J. Unparalleled Lithium and Sodium Superionic Conduction in Solid Electrolytes with Large Monovalent Cage-like Anions. Energy Environ. Sci. 2015, 8 (12), 3637-3645.

(18) Tang, W. S.; Matsuo, M.; Wu, H.; Stavila, V.; Zhou, W.; Talin, A. A.; Soloninin, A. V.; Skoryunov, R. V.; Babanova, O. A.; Skripov, A. V.; Unemoto, A.; Orimo, S.-I.; Udovic, T. J. Liquid-Like Ionic Conduction in Solid Lithium and Sodium MonocarbaCloso-Decaborates Near or at Room Temperature. $A d v . \quad$ Energy Mater. 2016, 6 (8), DOI: 10.1002/aenm.201502237.

(19) Tang, W. S.; Yoshida, K.; Soloninin, A. V.; Skoryunov, R. V.; Babanova, O. A.; Skripov, A. V.; Dimitrievska, M.; Stavila, V.; Orimo, S.; Udovic, T. J. Stabilizing Superionic-Conducting Structures via Mixed-Anion Solid Solutions of MonocarbaCloso-Borate Salts. ACS Energy Lett. 2016, 659664.

(20) Dey, A. N.; Miller, J. Primary Li / SOCl2 Cells VII . Effect of and Electrolyte Salts on the Performance. J. Electrochem. Soc. 1979, 126 (9), 1445-1451.

(21) Johnson, J. W.; Whittingham, M. S. Lithium Closoboranes as Electrolytes in Solid Cathode Lithium Cells. J. Electrochem. Soc. 1980, 127 (7), 1653-1654.

(22) Johnson, J. W.; Thompson, A. H. Lithium Closoboranes II . Stable Nonaqueous Electrolytes for Elevated Temperature Lithium Cells. J. Electrochem. Soc. 1981, 128 (4), 932-933.

(23) Johnson, J. W.; Brody, J. F. Lithium Closoborane Electrolytes III . Preparation and Characterization. J. Electrochem. Soc. 1982, 129 (10), 2213-2219.

(24) Rupich, M. W.; Foos, J. S.; Brummer, S. B. Characterization of Chloroclosoborane Acids as Electrolytes for Acid Fuel Cells. J. Electrochem. Soc. 1985, 132 (1), 119-122.
(25) Oshima, T.; Kajita, M.; Okuno, A. Development of Sodium-Sulfur Batteries. Int. J. Appl. Ceram. Technol. 2004, 1 (3), 269-276.

(26) Dufo-López, R.; Bernal-Agustín, J. L.; DomínguezNavarro, J. A. Generation Management Using Batteries in Wind Farms: Economical and Technical Analysis for Spain. Energy Policy 2009, 37 (1), 126139.

(27) Hansen, B. R. S.; Møller, K. T.; Paskevicius, M.; Dippel, A.-C.; Walter, P.; Webb, C. J.; Pistidda, C.; Bergemann, N.; Dornheim, M.; Klassen, T.; Jørgensen, J.-E.; Jensen, T. R. In Situ X-Ray Diffraction Environments for High-Pressure Reactions. J. Appl. Crystallogr. 2015, 48 (4), 12341241.

(28) Favre-Nicolin, V.; Černý, R. FOX, 'free Objects for Crystallography': a Modular Approach to Ab Initio Structure Determination from Powder Diffraction. J. Appl. Crystallogr. 2002, 35 (6), 734-743.

(29) Her, J.-H.; Zhou, W.; Stavila, V.; Brown, C. M.; Udovic, T. J. Role of Cation Size on the Structural Behavior of the Alkali-Metal Dodecahydro-ClosoDodecaborates. J. Phys. Chem. C 2009, 113 (26), 11187-11189.

(30) Verdal, N.; Her, J.-H.; Stavila, V.; Soloninin, A. V.; Babanova, O. A.; Skripov, A. V.; Udovic, T. J.; Rush, J. J. Complex High-Temperature Phase Transitions in $\mathrm{Li}_{2} \mathrm{~B}_{12} \mathrm{H}_{12}$ and $\mathrm{Na}_{2} \mathrm{~B}_{12} \mathrm{H}_{12}$. J. Solid State Chem. 2014, 212, 81-91.

(31) Tiritiris, I.; Schleid, T. The Crystal Structures of the Dicesium Dodecahalogeno-ClosoDodecaborates $\mathrm{Cs}_{2}\left[\mathrm{~B}_{12} \mathrm{X}_{12}\right](\mathrm{X}=\mathrm{Cl}, \mathrm{Br}, \mathrm{I})$ and Their Hydrates. Z Anorg Allg Chem 2004, 630, 1555-1563.

(32) Wu, H.; Tang, W. S.; Zhou, W.; Stavila, V.; Rush, J. J.; Udovic, T. J. The Structure of Monoclinic Na2B1oH1o: A Combined Diffraction, Spectroscopy, and Theoretical Approach. CrystEngComm 2015, 17 (18), 3533-3540.

(33) Wu, H.; Tang, W. S.; Zhou, W.; Tarver, J. D.; Stavila, V.; Brown, C. M.; Udovic, T. J. The LowTemperature Structural Behavior of Sodium 1Carba-Closo-Decaborate: NaCB9H1o. J. Solid State Chem. 2016, 243, 162-167.

(34) Frisch, M. J.; Trucks, G. W.; Schlegel, H. B.; Scuseria, G. E.; Robb, M. A.; Cheeseman, J. R.; Scalmani, G.; Barone, V.; Mennucci, B.; Petersson, G. A.; others. Gaussian ogW v. 7.o; Gaussian, Inc., Wallingford CT, 2009.

(35) Paskevicius, M.; Pitt, M. P.; Brown, D. H.; Sheppard, D. A.; Chumphongphan, S.; Buckley, C. E. First-Order Phase Transition in the Li2B12H12 System. Phys. Chem. Chem. Phys. 2013, 15 (38), 1582515828.

(36) Paskevicius, M.; Hansen, B. R. S.; Jørgensen, M.; Richter, B.; Jensen, T. R. Multifunctionality of Silver Closo-Boranes. Nat. Commun. 2017, in press, DOI: $10.1038 /$ ncomms15136.

(37) Her, J.-H.; Yousufuddin, M.; Zhou, W.; Jalisatgi, S. S.; Kulleck, J. G.; Zan, J. A.; Hwang, S.-J.; Bowman, 
R. C.; Udovic, T. J. Crystal Structure of Li2B12H12: A Possible Intermediate Species in the Decomposition of $\mathrm{LiBH}_{4}$. Inorg. Chem. 20o8, 47 (21), 97579759.

(38) Tiritiris, I.; Schleid, T. The Crystal Structure of Solvent-Free Silver Dodecachloro-ClosoDodecaborate $\mathrm{Ag}_{2}\left[\mathrm{~B}_{12} \mathrm{Cl}_{12}\right]$ from Aqueous Solution. Z. Für Anorg. Allg. Chem. 2003, 629 (4), 581583.

（39） Blanton, T.; Misture, S.; Dontula, N.; Zdzieszynski, S. In Situ High-Temperature X-Ray Diffraction Characterization of Silver Sulfide, Ag2S. Powder Diffr. 2011, 26 (Special Issue 02), 114-118.

(40) Tang, W. S.; Udovic, T. J.; Stavila, V. Altering the Structural Properties of $\mathrm{A}_{2} \mathrm{~B}_{12} \mathrm{H}_{12}$ Compounds via Cation and Anion Modifications. J. Alloys Compd. 2015, 645, Supplement 1, S200-S2O4.

(41) Stephenson, C. C.; Rice, D. W.; Stockmayer, W. H. Order-Disorder Transitions in the Alkali Borohydrides. J. Chem. Phys. 1955, 23 (10), 1960.

(42) Verdal, N.; Wu, H.; Udovic, T. J.; Stavila, V.; Zhou, W.; Rush, J. J. Evidence of a Transition to Reorientational Disorder in the Cubic Alkali-Metal Dodecahydro-Closo-Dodecaborates. J. Solid State Chem. 2011, 184 (11), 3110-3116.

(43) West, A. R. Solid Electrolytes and Mixed Ionicelectronic Conductors: An Applications Overview. J. Mater. Chem. 1991, I (2), 157-162.

(44) Rickert, H. Solid Ionic Conductors: Principles and Applications. Angew. Chem. Int. Ed. Engl. 1978, 17 (1), 37-46.
(45) Hayashi, A.; Noi, K.; Sakuda, A.; Tatsumisago, M. Superionic Glass-Ceramic Electrolytes for RoomTemperature Rechargeable Sodium Batteries. Nat. Commun. 2012, 3, 856.

(46) Sadikin, Y.; Brighi, M.; Schouwink, P.; Černý, R. Superionic Conduction of Sodium and Lithium in Anion-Mixed Hydroborates $\mathrm{Na}_{3} \mathrm{BH}_{4} \mathrm{~B}_{12} \mathrm{H}_{12}$ and (Lio.7Nao.3) $3 \mathrm{BH}_{4} \mathrm{~B} 12 \mathrm{H} 12$. Adv. Energy Mater. 2015, 5 (21), DOI: 10.1002/aenm.201501016.

(47) Wang, Y.; Richards, W. D.; Ong, S. P.; Miara, L. J.; Kim, J. C.; Mo, Y.; Ceder, G. Design Principles for Solid-State Lithium Superionic Conductors. Nat. Mater. 2015, 14 (10), 1026-1031.

(48) Cavallo, G.; Metrangolo, P.; Milani, R.; Pilati, T.; Priimagi, A.; Resnati, G.; Terraneo, G. The Halogen Bond. Chem. Rev. 2016, 116 (4), 2478-26o1.

(49) Bauzá, A.; Frontera, A. On the Versatility of $\mathrm{BH}_{2} \mathrm{X}$ $(\mathrm{X}=\mathrm{F}, \mathrm{Cl}, \mathrm{Br}$, and I) Compounds as Halogen-, Hydrogen-, and Triel-Bond Donors: An Ab Initio Study. ChemPhysChem 2016, 17 (20), 3181-3186.

(50) Rius, J.; Romerosa, A.; Teixidor, F.; Casabo, J.; Miravitlles, C. Phase Transitions in Cesium 7,8dicarbaundecaborate(12): A New OneDimensional Cesium Solid Electrolyte at $210{ }^{\circ} \mathrm{C}$. Inorg. Chem. 1991, 30 (6), 1376-1379.

(51) Zhao, T.; Zhou, J.; Wang, Q.; Jena, P. Like Charges Attract? J. Phys. Chem. Lett. 2016, 7 (14), 26892695 .

SYNOPSIS TOC: The halogenated sodium-closo-dodecaboranes possess impressive $\mathrm{Na}^{+}$ion conductivities (up to 0.162 $\mathrm{S} / \mathrm{cm}$ at $500{ }^{\circ} \mathrm{C}$ ). The halogen-rich anions exhibit anisotropic electron densities that could influence their transition temperature to a 'dynamic' polymorph that demonstrates 'liquid-like' ion conductivity.

\section{TOC Graphic}

\section{Electrostatic Potential}
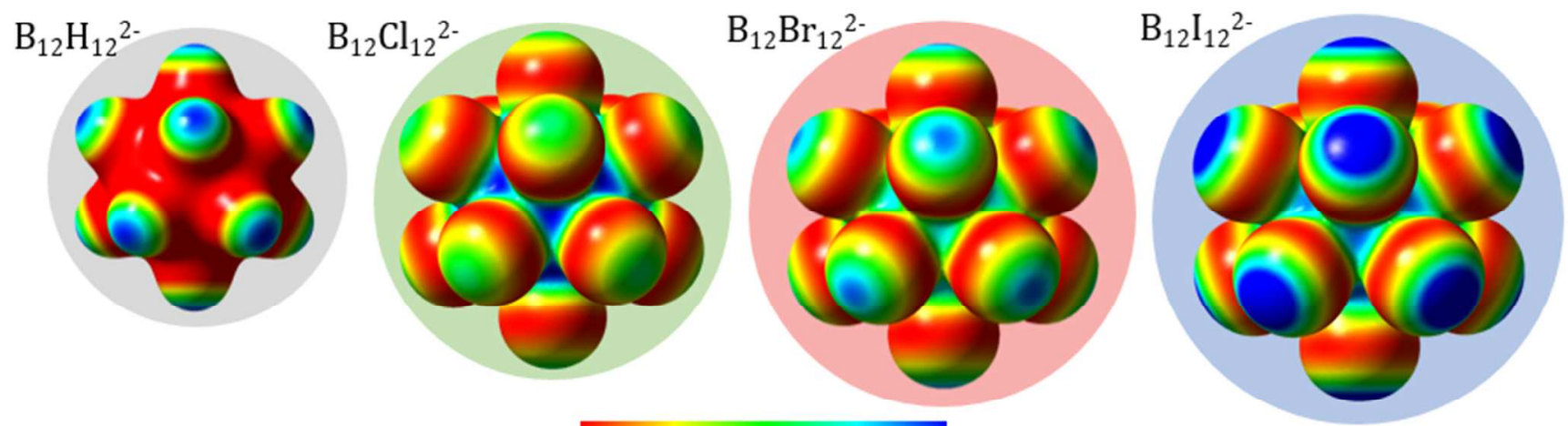

more negative

less negative 
2

3

4

5

6

7

8

9

10

11

12

13

14

15

16

17

18

19

20

21

22

23

24

25

26

27

28

29

30

31

32

33

34

35

36

37

38

39

40

41

42

43

44

45

46

47

48

49

50

51

52

53

54

55

56

57

58

59

60

ACS Paragon Plus Environment 